\title{
Vírus Sincicial Respiratório (VSR): Avanços Diagnósticos
}

\section{Respiratory Syncytial Virus (RSV): Diagnostic Advances}

Joelma Rodrigues Souza Gonçalves*, Carlos Alberto Bhering

Como citar esse artigo. Gonçalves,

J.R.S.; Bhering, C.A.; Vírus Sincicial

Respiratório (VSR): Avanços

Diagnósticos. Revista de Saúde. 2021 Dez./Mar.; 12 (1): 55-63.

\begin{abstract}
Resumo
O VSR é a principal causa de infecção aguda do trato respiratório superior e inferior em crianças com até 5 anos de idade e a forma grave da BVA em bebês e menores de 2 anos. O diagnóstico preciso e rápido permite a implementação de estratégias de prevenção e terapias antivirais apropriadas. Ultimamente, observou-se um aprimoramento nos testes para diagnóstico viral. Foram pesquisadas produções científicas de 2015 - 2020. Foram consultadas as bases de dados: Scielo, Bireme-Medline, Lilacs, Cochrane Library e Pubmed. Foram selecionadas 28 publicações científicas que preencheram os critérios de inclusão. A infecção pelo VSR pode ser diagnosticada por cultura celular; detecção direta rápida do antígeno viral, detecção do genoma do vírus por técnicas de diagnóstico rápido incluindo RT-PCR, RT-PCR em tempo real e RTPCR multiplex. Os mais inovadores métodos diagnósticos derivam do conceito de amplificação de ácidos nucleicos, dentre os quais se destacam os ensaios de PCR e suas variantes como a RT-qPCR que possibilita analisar quantitativamente a carga viral numa dada amostra. Destaca-se que o diagnóstico da BVA por VSR deve ser complementado com um teste laboratorial. Ressaltamos as vantagens dos Painéis Multiplex para firmar um diagnóstico preciso e detectar eventuais coinfecções virais e/ou bacterianas, além de evitar o uso desnecessário de antibióticos.

Palavras-chave: Vírus Sincicial Respiratório; Bronquiolite Viral Aguda.
\end{abstract}

\begin{abstract}
RSV is the main cause of acute upper and lower respiratory tract infection in children up to 5 years of age and the severe form of AVB in infants and children under 2 years of age. Accurate and rapid diagnosis allows the implementation of prevention strategies and appropriate antiviral therapies. Lately, there has been an improvement in tests for viral diagnosis. Scientific productions from 2015 to 2020 were researched. The databases were consulted: Scielo, BiremeMedline, Lilacs, Cochrane Library and Pubmed. 28 scientific publications that met the inclusion criteria were selected. RSV infection can be diagnosed by cell culture; rapid direct detection of viral antigen, detection of the virus genome by rapid diagnostic techniques including RT-PCR, real-time RT-PCR and RT-PCR Multiplex. The most innovative diagnostic methods derive from the concept of nucleic acid amplification, among which the PCR assays and their variants such as RT-qPCR stand out, which allows quantitative analysis of viral load in a given sample. It is noteworthy that the diagnosis of AVB by RSV should be complemented with a laboratory test. We emphasize the advantages of Multiplex Panels to establish an accurate diagnosis and detect possible viral and/or bacterial co-infections, besides avoiding unnecessary use of antibiotics.
\end{abstract}

Keywords: Respiratory Syncytial Virus; Acute Viral Bronchioliti.

\section{Introdução}

Infecções respiratórias são muito comuns, principalmente no primeiro ano de vida. Em grande parte são causadas por vírus, especialmente o Vírus Sincicial Respiratório (VSR), influenza e rinovírus. ${ }^{1}$ O VSR é a principal causa de infecção aguda do trato respiratório superior e inferior em crianças com até 5 anos de idade e o patógeno atribuído a forma grave da bronquiolite viral aguda (BVA) em bebês e menores de
2 anos. ${ }^{2,3,4}$

O VSR causa quadro mais prolongado e grave de BVA em comparação com outros agentes como o rinovírus, vírus da gripe e metapneumovírus humano. ${ }^{5}$ Devido a sua virulência, infecta até $70 \%$ da população pediátrica no primeiro ano de vida e quase todas as crianças até 2 anos de idade. ${ }^{2,6}$

A BVA é uma patologia que cursa com inflamação das vias aéreas de pequeno calibre dos pulmões, sendo de etiologia predominantemente viral, em geral 
acometendo bebês e crianças menores de 3 anos. $^{7} \mathrm{O}$ principal patógeno responsável pelas infecções é o VSR. ${ }^{7,8}$

Mundialmente, cerca de 3 milhões de hospitalizações e 200 mil mortes a cada ano são relacionadas a infecção pelo VSR. ${ }^{4}$ É um grande problema em saúde pública, sendo uma das maiores causas de atendimento em pronto socorro pediátrico e um dos principais motivos de internação no inverno. ${ }^{9}$ Por conseguinte, esse agente causa um grande impacto socioeconômico para os serviços de saúde de diversos países. ${ }^{3,10}$

Para diagnóstico do VSR os métodos usuais, como cultura viral e imunoensaios de fluorescência direta e indireta são demorados, trabalhosos e apresentam sensibilidade limitada. ${ }^{11}$ Os testes moleculares rápidos são de grande interesse para o diagnóstico de pacientes com infecção do trato respiratório, principalmente em enfermarias pediátricas durante surtos sazonais. ${ }^{12}$

$\mathrm{O}$ diagnóstico preciso e rápido de um agente viral pode auxiliar no monitoramento epidemiológico, além de permitir a implementação de estratégias de prevenção e terapias antivirais apropriadas. Nas últimas décadas, observou-se aprimoramento nos testes de diagnóstico viral, desde abordagens convencionais até a identificação por métodos sofisticados de detecção. (11) O teste rápido de diagnóstico do VSR otimiza o atendimento ao paciente e reduz os custos gerais de assistência médica, possibilitando otimizar a tomada de decisões quanto à necessidade de hospitalização e administração de terapia antimicrobiana (nos casos de coinfecção bacteriana)..$^{13}$

A relevância deste trabalho justifica-se pelo impacto clínico-epidemiológico das infecções pelo VSR e a demanda em estabelecer o diagnóstico rápido e preciso. Portanto, consideramos importante fazer uma revisão bibliográfica sobre o tema, enfatizando os principais avanços diagnósticos.

Este estudo teve como objetivo realizar uma revisão bibliográfica e descrever os principais avanços diagnósticos para detecção do Vírus Sincicial Respiratório na Prática clínica.

\section{Materiais e Métodos}

Foi realizada uma busca das principais produções científicas nos últimos 6 anos (2015-2020). Foram pesquisados artigos científicos, Guidelines e acervo médico científico produzido por Sociedades Médicas Especializadas. As bases de dados consultadas foram Scielo, Bireme-Medline, Lilacs, Cochrane Library e Pubmed. Os descritores utilizados foram: diagnóstico do vírus sincicial respiratório; diagnóstico de bronquiolite viral aguda por vírus sincicial respiratório; respiratory syncytial virus; acute viral bronchiolitis;
$R S V$ rapid tests; $R S V$ diagnostic assays; diagnosis of acute viral bronchiolitis. A busca às bases de dados resultou em 95 artigos sendo que 40 foram descartados por contemplarem estudos em modelos não-humanos ou se afastaram do recorte temporal explorado. Das 55 publicações restantes selecionou-se 28 produções científicas que preencheram critérios para subsidiar este estudo. Os critérios para inclusão foram publicações que discutissem especialmente elementos diagnósticos da bronquiolite viral aguda por vírus sincicial respiratório e os principais avanços diagnósticos disponíveis. Foram excluídos estudos que não preencheram os critérios de seleção ou estudos que se afastam do cerne desta revisão.

\section{Resultados}

\section{Considerações sobre o VSR}

O vírus se espalha pelo trato respiratório, formando sincícios no trato respiratório superior e avançando para o trato inferior. ${ }^{2}$ Ao infectar o epitélio bronquiolar ocorre aumento da secreção de muco, morte celular e descamação do epitélio seguido por infiltrado linfocítico peribronquiolar e edema submucoso. A obliteração das pequenas vias aéreas é resultado da combinação de detritos e edema intraluminal. ${ }^{8}$

Nas crianças acima de três anos e em adultos, o vírus causa sintomas leves como dor de garganta, tosse, dor de cabeça, febre baixa e mal estar. ${ }^{7,14}$ Comumente ocorre coriza, tosse e dispneia, em geral associada a broncoespasmo, produção de muco e chiado no peito. ${ }^{5,8}$ Nas formas graves, a infecção pelo VSR, em bebês e crianças pequenas pode causar insuficiência respiratória aguda e hipóxia, com demanda imediata de admissão em UTI pediátrica e suporte respiratório com ventilação mecânica. ${ }^{2,714}$

A abordagem diagnóstica baseia-se, usualmente nos sinais e sintomas não havendo em geral necessidade de utilizar recursos de diagnóstico laboratorial. ${ }^{2,5,15,16}$ Entretanto, o diagnóstico de bronquiolite aguda por VSR não pode ser estabelecido até a confirmação positiva do VSR em amostras dos pacientes pois, sinais e sintomas do trato respiratório podem ser causados por outros patógenos. ${ }^{5,17}$

Para tanto, testes para detecção de vírus respiratório podem ser usados para corroborar com o diagnóstico de infecção viral, e não bacteriana. ${ }^{18}$ Assim, o diagnóstico preciso e rápido de patógenos virais é importante para definir o tratamento adequado e minimizar o uso desnecessário de antibióticos. ${ }^{11,13,17,19}$ 


\section{Diagnóstico Laboratorial}

O diagnóstico de infecções respiratórias causadas por vírus são apoiados na utilização de métodos convencionais como isolamento da partícula viral por cultivo celular e detecção antigênica por ensaios de imunofluorescência. ${ }^{20,21}$

A infecção pelo VSR pode ser diagnosticada por diversas técnicas laboratoriais: Cultura em meio celular; detecção direta rápida do antígeno viral (RADT) ou detecção do genoma do vírus por técnicas de diagnóstico rápido incluindo reação em cadeia da polimerase com transcrição reversa (RT-PCR), RTPCR em tempo real e RT-PCR multiplex; pode ainda ser realizado por testes sorológicos, como por exemplo ensaios de imunofluorescência direta (DFA). ${ }^{13,15,16,20,22-24}$

Didaticamente, o diagnóstico laboratorial por Testes Rápidos são agrupados em três formatos: Testes Imunocromatográficos (ICR), Imunoensaios Enzimáticos (EIAs) e Imunoensaios Ópticos (OIAs)..$^{15,16}$ A maioria dos ensaios possui como alvo proteínas do nucleocapsídeo do VSR e a glicoproteína de superfície F (VSR-F). ${ }^{15}$ Os testes ICR e EIAs apresentam como principal vantagem a facilidade de execução e a capacidade de disponibilizar resultados em aproximadamente 10 minutos. ${ }^{16}$

A Sociedade Brasileira de Pediatria (SBP) posiciona-se enfaticamente ao descrever os benefícios dos testes de detecção rápida do VSR como Testes Point of Care (POC), uma vez que, além da praticidade de execução e rapidez de obtenção de resultados possibilita tomadas de decisão precoces no manejo da bronquiolite aguda por VSR. ${ }^{16}$

\section{Detecção de Antígenos Virais}

São pesquisados antígenos do VSR, utilizando detecção por técnicas de imunoensaios de fluorescência direta (DFA) e imunoensaios de fluorescência indireta (IFA) ou testes rápidos de detecção antigênica. ${ }^{16,17}$

\subsection{Teste Direto de Anticorpos Fluorescentes (Direct Fluorescent Antibody Testing)}

O Teste Direto de Anticorpos Fluorescentes (DFA) ou Imunofluorescência Direta é um teste rápido de diagnóstico que requer amostragem de células epiteliais coletadas por Swab nasal e é aplicável inclusive às amostras nasofaríngeas. ${ }^{15} \mathrm{O}$ teste baseia-se na exclusão microscópica de proteínas do vírus nas células do hospedeiro por intermédio de anticorpos marcados. Pode-se obter os resultados de 2 a 4 horas. $^{2}$ Testes DFA apresentam maior acurácia na discriminação do patógeno. Todavia, requer análise mais especializada na reavaliação das amostragens. ${ }^{16,17}$ É utilizado amplamente para detecção do VSR nos laboratórios de análises clínicas devido a rapidez e simplicidade de execução. Apresenta sensibilidade de $94 \%$ e especificidade de $96,8 \%{ }^{2,11}$ Por essa razão, esse ensaio pode ser realizado em países que carecem de recursos, pois pode minimizar hospitalizações e limitar o uso de antibióticos desnecessariamente. ${ }^{11}$

\subsection{Teste Indireto de Anticorpos Fluorescentes (Indirect Fluorescent Antibody Testing)}

O Teste Indireto de Anticorpos Fluorescentes (IFA) ou Imunofluorescência Indireta é um método eficaz e com frequência utilizado de modo complementar. É passível de diagnosticar além do VSR, os vírus influenza A e B, parainfluenza, adenovírus e metapneumovírus. Todavia, fatores como titulação viral, idade do paciente e o tempo do teste em relação ao início dos sintomas podem declinar o valor da sensibilidade na detecção do VSR. O método IFA apresenta sensibilidade 85,7\% e especificidade de 73,6\%, quando comparado ao RTPCR. 16,21

\subsection{Imunoensaio de Fluxo Lateral (Lateral flow immunoassay - LFIA)}

O Imunoensaio de Fluxo Lateral(LFIA) pertence aos testes de detecção rápida do VSR, com base em uma técnica imunocromatográfica utilizando amostragens de aspirado ou lavagem nasais. Na presente data, diversos kits são comercializados. Apresentam sensibilidade e especificidade superiores a $90 \%$ e $95 \%$, respectivamente. Todavia, a sensibilidade e especificidade podem oscilar dependendo do fabricante. Exemplos de kits LFIA incluem: Remel ${ }^{\mathrm{TM}}$ Xpect $^{\mathrm{TM}} \mathrm{RSV}$; BD DirectigenTM EZ RSV; Abbott ${ }^{\mathrm{TM}}$ BinaxNOW TM RSV; RSV RespiStrip. ${ }^{11}$

O QuickVue ${ }^{\circledR}$ RSV é um imunoensaio que possibilita a detecção rápida e qualitativa do antígeno VSR-F (proteína de fusão viral F). Utiliza amostras coletadas por swab nasofaríngeo, aspirado nasofaríngeo ou amostras de lavagem nasal e nasofaríngeas de pacientes sintomáticos. O teste é destinado ao uso como um auxiliar no diagnóstico de infecções por VSR. ${ }^{24}$

\subsection{Imunoensaio de Micro Matrizes (Microarray Immunoassay-MAIA)}

Microarray é uma tecnologia em ascensão que fornece uma plataforma versátil para muitas aplicações de diagnóstico e pesquisa. As micro matrizes de proteína são versões em miniatura de ensaios tradicionais, possibilitando a identificação paralela de alto rendimento de múltiplos biomarcadores em amostras sorológicas ou outras amostragens, em um único teste. ${ }^{25}$

O teste Multiplex Microarray Immunoassay é um ensaio sorológico multiplexado de micro matrizes, idealizado por Kazakova et al, 2019 para a identificação 
simultânea de anticorpos IgG séricos para diversos vírus, incluindo o VSR, adenovírus (tipo 5) e diferentes subtipos de influenza A (H1N1, H3N2) e B (Victoria, Yamagata). Este ensaio permite a obtenção de dados quantitativos da soropositividade na amostra, além de estimar taxas de reinfecção. Resumidamente, este ensaio utiliza nanopartículas de conversão ascendente

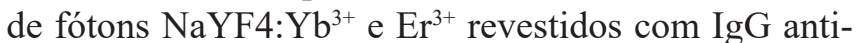
humano (anti-hIgG) para detectar anticorpos IgG séricos ligados aos pontos da matriz. ${ }^{25}$

\section{Testes Moleculares de Detecção do VSR}

Essa modalidade requer treinamento, implementação de sistemas de qualidade e infraestrutura robustos para subsidiar e executar esses testes. Dos diversos ensaios comercializados, muitos compartilham características em comum. ${ }^{15}$

\subsection{Reação em Cadeia da Polimerase com Transcrição Reversa (Reverse Transcription Polymerase Chain Reaction - RT PCR)}

Ultimamente, em decorrência de sua elevada sensibilidade e especificidade, testes utilizando RTPCR tornaram-se a metodologia usual em detecção de patógenos. Entretanto, sua implementação requer recursos humanos especializados e laboratórios munidosde equipamentos de termociclagem de alto custo. $^{19,23,26}$

A técnica de PCR é baseada no método de $R T$ PCR aninhada, que envolve primers externo e interno, desenhados a partir do gene F doVSR-A ou VSR-B. Logo, pode detectar baixos títulos virais e com elevada sensibilidade. ${ }^{11}$ A RT-PCR em tempo real apresenta muitas vantagens na identificação de vírus, incluindo suas elevadas sensibilidade e especificidades, capacidade de quantificar amostras e simplicidade operacional. .9,22,27 $^{19}$ Através de modificações na abordagem convencional de PCR, novos métodos de detecção por esse método foram desenvolvidos. ${ }^{11}$

A RT-qPCR (PCR quantitativa em tempo real) é um método rápido, específico e sensível para detecção, delineação de subgrupo e quantificação de agentes patogênicos. Este ensaio eleva a sensibilidade da PCR convencional. Para tanto, requer o emprego de dois conjuntos de pares iniciador-sonda (primer-probe), advindos da sequência nucleotídica do nucleocapsídeo (N) ou do gene de fusão (F) direcionado para o VSR-A e VSR-B, respectivamente. ${ }^{11}$

\subsection{PCR em Tempo Real aninhada a tubo (One-Tube Nested Real-Time PCR [OTNRT-PCR])}

$\mathrm{O}$ teste de OTNRT-PCR apresenta maior sensibilidade que o RTqPCR para identificação doVSR em amostras clínicas. Além disso, o método de amplificação rápida por transcrição reversa auxiliado por recombinase (rapid reverse-transcription recombinaseaided amplification [RT-RAA] assay) foi desenvolvido como um método baseado em diagnóstico molecular para identificar os genomas do subgrupo VSR A e B em amostras clínicas. São utilizadas mix de enzimas que incluem a proteína de ligação a DNA de fita simples (SSB), recombinase UvsX e DNA polimerase para localizar produtos de amplificação (amplicons) de RNA do VSR. Esse teste pode ser executado em menos de 30 min e apresenta elevada especificidade. ${ }^{11}$

A detecção do VSR nos ensaios anteriormente descritos pode estar associada a pesquisa de poucos patógenos (ex: influenza A e B) ou pode ser realizada em extensos painéis multiplexados (Multiplex assays) de pesquisa de patógenos respiratórios. ${ }^{15}$

Os kits diagnósticos para detecção do VSR, seja isoladamente (Singleplex) ou kits que além do VSR pesquisam concomitantemente outro patógeno respiratório que na maioria das vezes é o vírus influenza (duplex) são apresentados, resumidamente no quadro 1.

Quadro 1. Testes Singleplex e Duplex para Pesquisa do VSR.

\begin{tabular}{|c|c|c|}
\hline Teste & Patógenos Pesquisados & Referência \\
\hline Alere i RSV assay & VSR A/B & 13 \\
\hline RT-SIBA $^{\circledR}$ RSV assay & VSR A/B & 12 \\
\hline QuickVue ${ }^{\circledR}$ RSV Test Kit & VSR & 24 \\
\hline Solana RSV + hMPV assay & VSR, hMPV & 13 \\
\hline $\operatorname{cobas}^{\circledR}$ Liat Influenza A/B/RSV & VSR A/B, Flu A/B & 13 \\
\hline Xpert $^{\circledR}$ Flu/RSV XC assay & VSR A/B, Flu A/B & 12 \\
\hline Prodesse $^{\circledR}$ ProFlu $^{\circledR}+$ Assay & VSR A/B, Flu A/B & 15 \\
\hline
\end{tabular}

Abreviações: VSR A/B (vírus sincicial respiratório A/B); Flu A/B (Influenza A / B); hMPV (metapneumovírus humano) 
Ultimamente, foram idealizados primers modificados por ácidos nucleicos bloqueados (LNA) e desenhado um ensaio multiplex de OTNRT-PCR (mOTNRT-PCR) com a propriedade de identificar simultaneamente VSR, rinovírus e metapneumovírus com maior sensibilidade e menores custos quando comparado ao RT-qPCR. ${ }^{11}$

\subsection{Detecção Multiplex de Patógenos Respiratórios em Alta Complexidade}

Embora vírus respiratórios isolados possam ser identificados em pacientes sintomáticos, outros vírus respiratórios também podem existir simultaneamente no paciente; principalmente em crianças menores de cinco anos, que podem apresentar co-infecções. ${ }^{11}$

$\mathrm{O}$ método Multiplex PCR em tempo real (Multiplex RT-PCR) possibilita a identificação simultânea de vários vírus respiratórios em curto espaço de tempo. ${ }^{2} 15$ Comparativamente ao ensaio Singleplex, a abordagem de diagnóstico Multiplex apresenta maior taxa de transferência de amostra, menor tempo resposta e menor quantidade de amostra requerida no teste. ${ }^{11}$ Essas plataformas multiplex possibilitam a detecção simultânea de até 20 agentes virais ou 18 partículas virais incluindo de 2 a 3 bactérias atípicas ou ainda 18 vírus e 4 bactérias típicas. ${ }^{1,16} \mathrm{Em}$ termos gerais, esses testes possuem desempenhos comparáveis em sensibilidade, especificidade e detecção de co-infecções. ${ }^{1}$
Estão disponíveis kits comerciais de PCR Multiplex capazes de identificar diversos vírus em um mesmo teste, sendo reconhecidos como testes de escolha para diagnóstico de infecções respiratórias. ${ }^{11,12,16,27}$ Ensaios Multiplex, como o eSensor ${ }^{\circledR}$ RPV Respiratory Viral Panel podem detectar múltiplos patógenos virais em um único ensaio quando o paciente apresentar coinfecção por múltiplos vírus. ${ }^{15}$ Os principais ensaios multiplex disponíveis são apresentados no quadro 2, que além de citar os diversos kits comercializados, elencam todos os patógenos pesquisados em cada ensaio (além do VSR).

O Luminex NxTAG (NxTAG-RPP) é um novo sistema multiplex de PCR em tempo real de alto desempenho para pesquisa de patógenos respiratórios, atualizado a partir do teste $x T A G$ Respiratory Viral Panel Fastv2 assay. ${ }^{11}$

O Panther Fusion respiratory assay foi criado para detectar vários vírus respiratórios e, consiste em três painéis PCR multiplexados em tempo real para detecção de vírus influenza A e B, VSR, parainfluenza, adenovírus, metapneumovírus e rinovírus. ${ }^{11}$

OFTD21 kit é um ensaio comercial multiplexado de amplificação de ácidos nucleicos. Este teste apresenta sensibilidade de $90,7 \%$ e especificidade de $100 \% .{ }^{11}$

O GeXP assay é um teste multiplex de RT-PCR desenvolvido para identificar 16 vírus respiratórios diferentes simultaneamente. Apresenta elevada

Quadro 2. Testes para Pesquisa do VSR em Ensaios MULTIPLEX de Detecção para Patógenos Respiratórios

\begin{tabular}{|c|c|c|}
\hline Ensaio & Patógenos Pesquisados & Referência \\
\hline mOTNRT-PCR & VSR, hRV, hMPV. & 11 \\
\hline $\begin{array}{l}\text { Panther fusion } \\
\text { respiratory assay }\end{array}$ & Flu A/B, RSV, PIV, hAdV, hMPV, hRV. & 11 \\
\hline FTD21 kit & $\begin{array}{l}\text { hAdV, VSR A/B, Cov (229E, OC43, NL63, HKU1), hPIV } \\
\text { 1/2/3/4, Flu A (H1, H1-2009), Flu B, hRV, hMPV A/B. }\end{array}$ & 11 \\
\hline GeXP assay & $\begin{array}{l}\text { (Flu A (H1), Flu B, hPIV 1/2/3, hRV, hMPV, hAdV, VSR } \\
\text { A/B, Cov (229E, OC43, NL63 e HKU1), hBoV. }\end{array}$ & 11 \\
\hline $\begin{array}{l}\text { Qiagen ResPlex II } \\
\text { V2.0 kit }\end{array}$ & $\begin{array}{l}\text { (A/B, hPIV 1/2/3/4, VSR, hMPV, hRV, hEV, hBoV, hAdV, } \\
\text { coronavírus (229E, OC43, NL63, HKU1) e FluA (pdm09). }\end{array}$ & 11 \\
\hline $\begin{array}{l}\text { FilmArray } \\
\text { multiplex PCR } \\
\text { system }\end{array}$ & $\begin{array}{l}\text { hAdV, VSR A/B, Cov (229E, OC43, NL63, HKU1), hMPV, } \\
\text { hRV/hEV, Flu A (H1, H1-2009, H3), Flu B, PIV 1/2/3/4. }\end{array}$ & 11 \\
\hline $\begin{array}{l}\text { Anyplex }{ }^{T M} \text { II RV16 } \\
\text { Detection Kit }\end{array}$ & $\begin{array}{l}\text { hAdV, Flu A/B, PIV 1/2/3/4, hRV, hBoV 1/2/3/4, Cov } \\
\text { (229E, OC43, NL63), hEV, hMPV, VSR A/B. }\end{array}$ & 12 \\
\hline $\begin{array}{l}\text { eSensor }^{\mathbb{B}} \\
\text { Respiratory Viral } \\
\text { Panel }\end{array}$ & $\begin{array}{l}\text { Flu A (H1, H3, H1N1 2009), Flu B, VSR A/B, PIV 1/2/3, } \\
\text { hRV, hMPV, hAdV B/C/E. }\end{array}$ & 15 \\
\hline $\begin{array}{l}\text { Seeplex }{ }^{\circledR} R V 15 \\
\text { ACE Detection }\end{array}$ & $\begin{array}{l}\text { hPIV 1/2/3/4, hAdV, Cov (229E, OC43,NL63), Flu A/B, } \\
\text { VSR A/B, hRV A/B/C, hBoV 1/2/3/4, hEV, hMPV. }\end{array}$ & 15 \\
\hline$N x T A G^{\mathbb{R}}-R P P$ & $\begin{array}{l}\text { Vírus: Flu B, Flu A (H1, H3), VSR A/B, hAdV, hRV/hEV, } \\
\text { PIV 1/2/3/4, hBoV, Cov (229E, OC43, NL63, HKU1) } \\
\text { Bactérias: C. Pneumoniae; M. Pneumoniae; L. Pneumophila. }\end{array}$ & 11 \\
\hline
\end{tabular}


sensibilidade e especificidade na detecção vírus respiratórios. ${ }^{11}$

O Qiagen ResPlex II V2.0 kit é uma plataforma multiplexada que utiliza amplificação por RT-PCR, enriquecida com alvos e combinada com deteç̧ão de arranjos de matriz em suspensão. Detecta até 17 vírus respiratórios, incluindo o VSR. A Sensibilidade para VSR é relativamente baixa, mas a especificidade do teste vai de $92,9 \%$ a $100 \% .{ }^{11}$

O FilmArray multiplex PCR system é um painel de PCR multiplex com capacidade de detectar 17 agentes virais, além de duas espécies de bactérias. Ao ser comparado ao Prodesse assay, apresentou sensibilidade de $100 \%$ e especificidade de $99,5 \%{ }^{11}$

O Anyplex II RV16 Detection Kit é uma plataforma multiplex capaz de identificar simultaneamente os vírus respiratórios mais prevalentes e de maior importância clínica, incluindo VSR-A e VSR-B. ${ }^{12}$

O cobas TM Liat Influenza $A / B$ and RSV é um ensaio de RT-PCR em tempo real. O teste pesquisa um gene de proteínas não estrutural para influenza A e B e um gene de proteína de matriz para o VSR. Utiliza amostras de swab nasofaríngeo, produzindo resultados em 20 min. $^{13}$

O teste Solana RSV + hMPV assay amplifica e identifica RNA viral de amostras colhidas da nasofaringe. Sequências-alvo para VSR e metapneumovírus humano (hMVP) são amplificadas utilizando-se reação isotérmica da transcriptase reversa helicase-dependente em presença de sondas fluorescentes alvo-específicos. ${ }^{13}$

\subsection{Amplificação Baseada em Invasão da Cadeia de Transcrição Reversa (Reverse Transcription Strand Invasion based amplification - RT-SIBA)}

O RT-SIBA é um método de amplificação isotérmica para deteç̧ão de ácidos nucleicos por transcrição reversa para diagnóstico rápido do VSR. Apresenta excelente sensibilidade e especificidade. ${ }^{11,12}$ Pode detectar até 10 cópias de RNA do VRS em 10 min. ${ }^{11}$ Resumidamente, o RT-SIBA inclui transcrição reversa do RNA do VSR para o cDNA e amplificação e detecção imediatas sob condições de reação isotérmica. Um oligonucleotídeo de fita simples de invasão separa o DNA alvo (fita dupla) levando à formação de um "modelo de alvo" de fita simples seguido por extensão de polimerase-dependente do alvo. $O$ teste RTSIBA ${ }^{\circledR} R S V$ foi idealizado para identificar VSR A/B. Possibilita obter resultados de $30 \mathrm{~min}$ a uma hora. É de fácil execução, processa até 12 amostras simultâneas sendo adequado como teste rápido de diagnóstico. ${ }^{12}$

1.9 Sequenciamento do Genoma Inteiro/ Sequenciamento de Próxima Geração (Whole
Genome Sequencing - WGS / Next-Generation Sequencing - NGS)

O Sequenciamento do Genoma Inteiro (WGS) possibilita a detecção de eventos e surtos de transmissão, o que nem sempre é viável com sequências sub-genômicas. ${ }^{11} \mathrm{O}$ WGS e o NGS ainda não chegaram ao cenário clínico como uma ferramenta diagnóstica, inicialmente. Um dos obstáculos é que sequências do genoma do VSR (RNA) ou mesmo as sequências genômicas de RNA/DNA de qualquer outro patógeno podem não ser o "alvo dominante" e podem estar escassas na amostra clínica. ${ }^{15}$

O Ensaio de Sequenciamento de Próxima Geração (NGS) revelou eficácia de identificar coinfecção em pacientes acometidos gravemente por pneumonia e obteve performance adequada para diagnóstico de pneumonia grave quando equiparada com métodos convencionais. ${ }^{11} \mathrm{~A}$ implementação rotineira com a técnica de NGS será favorecida com tecnologia da computação e redução dos custos de execução. Enquanto isso, o NGS desempenhará papel crescente na identificação e caracterização do sorotipo em casos especiais. Além da função diagnóstica, o NGS pode auxiliar na detecção dos índices de mutação assim como os padrões de circulação do VSR A/B no mundo. ${ }^{15}$

\subsection{Técnica de Amplificação isotérmica (Isothermal Amplification Technique)}

Aperfeiçoada nos últimos anos, este método apresenta-se como uma possível alternativa as técnicas de PCR. As técnicas estudadas são: Amplificação Baseada em Sequência de Ácidos Nucleicos (nucleic acid-sequence-based amplification - NASBA); Amplificação Isotérmica Mediada por Alça (loopmediated isothermal amplification - LAMP); Amplificação Helicase Dependente (helicase-dependent amplification - HDA); Amplificação de Recombinase Polimerase (recombinase polymerase amplification - RPA) e Amplificação Auxiliada por Recombinase (recombinase aided amplification - RAA). ${ }^{23,28}$

O teste duplex-rt RAA Assay é um ensaio molecular que utiliza o conceito de amplificação isotérmica através da técnica de RAA. Possui rápida execução, baixo custo associado a economia de mão de obra e aos reagentes liofilizados, o que se traduz em praticidade para armazenamento e transporte. Essas características favorecem a inclusão do duplex-rtRAA assay como uma possível ferramenta diagnóstica à beira-de-leito para diagnóstico do VSR.A obtenção dos resultados ocorre em $20 \mathrm{~min}$. Apresenta elevada sensibilidade e especificidades. Ao ser comparado com o RT-qPCR apresentou $100 \%$ de consistência nos resultados. ${ }^{23}$

A LAMP é um método de diagnóstico que utiliza 
4 a 6 primers para amplificar uma dada sequência-alvo por deslocamento de cadeia auxiliado pela Enzima DNA Polimerase Bst. Ao se combinar a LAMP com enzimas que exibem atividade de transcriptase reversa, é possível amplificar sequências de patógenos cujo material genético é RNA. Neste caso, passa a ser denominada LAMP de Transcrição Reversa (RT-LAMP). Neste teste desenvolveu-se seis primers específicos direcionados contra regiões conservadas de genes que expressam a proteína da matriz (M) e o nucleocapsídeo VSR A e B. O tempo médio para obtenção dos resultados no RTLAMPé 19,4 min. Possui sensibilidade de 93,59\% e especificidade $92,92 \% .^{28}$

\subsection{Cultura e Isolamento do VSR}

Técnicas para diagnosticar VSR incluem cultivo em tubos e "frascos em concha" (shell vials) e posterior detecção por imunofluorescência direta ou detecção viral por imunoensaios enzimáticos. Dentre as várias linhagens celulares para cultivo podemos citar as células de rins de embriões humanos e células Hep-2; além de células de rim de macaco Rhesus e culturas convencionais em "frascos tipo concha" com fibroblastos de prepúcio humano. Há disponível o kit de cultura R-mix shell vials que possui uma mistura de células de pulmão de minque (Mv1Lu) e células de adenocarcinoma humano (A549). ${ }^{15}$

Uma vantagem em cultura de vírus é a possibilidade de tipificação antigênica bem como a determinação de susceptibilidade a drogas antivirais. ${ }^{16}$ Dentre as desvantagens destaca-se o elevado tempo de obtenção dos resultados, necessidade de grande infraestrutura laboratorial, custo elevado e dificuldade técnica de execução. ${ }^{2,16,17,21,23}$

\section{Técnicas de Coleta de Secreção}

A sensibilidade e a especificidade dos métodos diagnósticos são influenciadas pela qualidade e tipo de amostras clínicas a serem examinadas e testadas. Dessa forma, torna-se imperativo padronizar o processo de coleta de secreções. Por conseguinte, foram padronizados pela SBP (2017) os Aspirados de Nasofaringe e Swabs de Rayon (dotados de revestimento de pequenas fibras, alocadas transversalmente em relação a haste). O lavado nasal ou aspirado nasofaríngeo possuem maior sensibilidade para detecção do VSR. Todavia, a utilização de coletas por swab revestido com fibras de nylon eleva a qualidade do material coletado aumentando o rendimento da amostragem. Os swab de algodão não são recomendados, uma vez que comprometem os resultados de ensaios moleculares. Após coletadas, as amostras devem ser mantidas entre $4^{\circ}$ e $8^{\circ} \mathrm{C}$ e enviadas ao laboratório. ${ }^{16}$

\section{Discussão}

Alguns autores defendem a proposição que num contexto clínico epidemiológico condizente (período sazonal), o diagnóstico da BVA por VSR, pode basear-se apenas em achados clínicos típicos como tosse, coriza, congestão nasal dentre outros. Toda via, deve-se ressaltar que outros vírus como rinovírus e metapneumovírus humano podem causar BVA. Não obstante a isto, em apresentações graves da doença pode haver dúvida no diagnóstico e inclusive coinfecção por bactérias.

Partindo dessa premissa, observou-se que o diagnóstico unicamente clínico foi facilmente refutado por diversos autores os quais apoiam fortemente a utilização de testes diagnósticos confirmatórios para detecção do VSR. Ao explorar as modalidades em diagnóstico laboratorial foram identificados não apenas testes convencionais como ensaios de imunofluorescência direta e indireta, mas também sofisticados métodos de detecção do VSR.

Os testes de DFA possuem boa sensibilidade e especificidade assim como os testes IFA. ${ }^{15,16}$ Resultados estão disponíveis em 2 a 4 horas e podem ser largamente utilizados em regiões com poucos recursos. ${ }^{2}$ Testes de LFIA são testes rápidos de detecção, possuem elevadas sensibilidade (90\%) e especificidade (95\%). Apesar de ser um método relativamente novo, já são comercializados vários kits de LFIA. ${ }^{11}$ Outro teste muito sofisticado cujas aplicações não apenas são em diagnóstico mas também com uma vertente em pesquisas é a técnica de imunoensaio com micro matrizes. Esse mesmo conceito foi aperfeiçoado para desenvolver o teste Multiplex Microarray Imunoassay, no qual é possível detectar múltiplos vírus por meio de detecção de anticorpos, além de titulação seriada, sendo possível de estimar taxas de reinfecções. ${ }^{25}$

Sem dúvida os mais inovadores métodos diagnósticos derivam do conceito de amplificação de ácidos nucleicos. Dentre os quais se destacam os ensaios de PCR e suas variantes como a RT-qPCR que possibilita analisar quantitativamente a carga viral numa dada amostra. ${ }^{11}$ A PCR em tempo real, além de elevadas sensibilidade e especificidade possui ainda facilidade de execução. ${ }^{22,27}$ Outras técnicas evoluíram da PCR e alcançaram maiores sensibilidades para detecção do VSR. São eles: a OTNRT-PCRe a RT-RAA. ${ }^{11}$

Por outro lado, os métodos anteriormente descritos pesquisam apenas alguns patógenos (incluindo o VSR). No entanto, muitos autores defendem abordagem de pesquisa de múltiplos patógenos, uma vez que, especialmente em crianças graves e internadas em UTI pediátrica podem estar coinfectados com outros vírus e/ou bactérias. Dessa forma, foram desenhados diversos testes para pesquisa para múltiplos patógenos respiratórios. O teste $F T D 21$ kit possui capacidade de 
pesquisar 21 agentes patogênicos respiratórios e ainda com $100 \%$ de especificidade. O Film Array Multiplex PCR System pode pesquisar 17 vírus e 2 bactérias no mesmo kit, com $100 \%$ de sensibilidade e mais de $99 \%$ de especificidade. ${ }^{11}$

Outro método baseado em PCR é o RT-SIBA. Esse teste foi criado para detectar os sorogrupos A e B do VSR e fornecer resultados em 30 min a 1 hora. ${ }^{11,12}$

O WGS e o NGS parecem ferramentas promissoras para diagnosticar o VSR. Entretanto há poucas descriçõessobre essemétodo eporconsequência ainda não está disponível para comercialização. ${ }^{11,15}$

Testes baseados em amplificação isotérmica dos ácidos nucléicos estão sendo aperfeiçoados, como as técnicas: NASBA, LAMP, HDA, RPA e RAA. ${ }^{23,28}$ Seguindo esse conceito, recentemente foi desenvolvido o duplex-rtRAA assay. Este teste foi desenvolvido para ser uma ferramenta diagnóstica complementar aplicada à beira do leito. Promete fornecer resultados em até 20 min. Não obstante a isso, os idealizadores enfatizam ser de baixo custo, a praticidade e facilidade de realização. ${ }^{23}$

Por último, analisando as descrições sobre cultura de vírus, os autores classificam esse método comodemoradoededifícil realização, demandaelevada infraestrutura e recursos humanos adequadamente capacitados. As vantagens descritas restringem-se a possibilidade de isolamento da partícula viral e testagem para susceptibilidade a drogas.

\section{Considerações Finais}

Esta revisão possibilitou a compreensão ampliada dos impactos causados pelo vírus sincicial respiratório em escala global, especialmente por tratase de uma patologia altamente contagiosa, que ainda não possui vacina, acarreta muitos gastos em saúde ao erário público e possui ainda heterogeneidade clínica.

Desta forma, autores desta revisão apoiam fortemente a imprescindível demanda em estabelecer o diagnóstico rápido e preciso da infecção por VSR. Destaca-se que o diagnóstico da BVA por VSR deve ser complementado com um teste laboratorial. Considerando a grande diversidade de testes diagnósticos disponíveis, recomendamos que idealmente cada instituição construa protocolos de diagnóstico laboratorial para condução clínica de casos suspeitos de VSR.

Ressaltamos as vantagens dos Painéis Multiplex para firmar um diagnóstico preciso e detectar eventuais coinfecções virais e/ou bacterianas, além de evitar o uso desnecessário de antibióticos. Entretanto, deve-se salientar que esses exames ainda não estão amplamente disponíveis na prática médica.

\section{Referências bibliográficas}

1. Esposito S, Mencacci A, Cenci E, Camilloni B, Silvestri E, Principi N. Multiplex Platforms for the Identification of Respiratory Pathogens: Are They Useful in Pediatric Clinical Practice? Front Cell Infect Microbiol 9:196. doi: 10.3389/fcimb.2019.00196

2. Alharbi AS, Alqwaiee M, Al-Hindi M, Mosalli R, Al-Shamrani A, Alharbi S, et al. Bronchiolitis in children: The Saudi initiative of bronchiolitis diagnosis, management, and prevention (SIBRO). Ann Thorac Med 2018; 13(3): 127-143. DOI: 10.4103/atm.ATM_60_18.

3. Acevedo OA, Díaz FE, Beals TE, Benavente FM, Soto JA, EscobarVera J, et al. Contribution of Fc $\gamma$ Receptor-Mediated Immunity to the Pathogenesis Caused by the Human Respiratory Syncytial Virus. Front Cell Infect Microbiol 9;75. doi: 10.3389/fcimb.2019.00075.

4. Jung J, Seo E, Yoo RN, Sung H, Lee J. Clinical significance of viralbacterial codetection among young children with respiratory tract infection. Medicine: January 2020 - Volume 99 - Issue 2 - pe18504 doi: 10.1097 MD.0000000000018504

5. Pickles RJ, DeVincenzo JP. Respiratory syncytial virus (RSV) and its propensity for causing bronchiolitis. J Pathol 2015; 235: 266-276. DOI: $10.1002 /$ path.4462.

6. Ruckwardt TJ, Morabito KM, Graham BS. Determinants of early life immune responses to RSV infection. Current Opinion in Virology 2016 16:151-157. http://dx.doi.org/10.1016/j.coviro.2016.01.003.

7. Jat KR, Mathew JL. Continuous positive airway pressure (CPAP) for acute bronchiolitis in children. Cochrane Database of Systematic Reviews 2019, Issue 1. DOI: 10.1002/14651858.CD010473.pub3.

8. Liet JM, Ducruet T, Gupta V, Cambonie G. Heliox inhalation therapy for bronchiolitis in infants. Cochrane Database of Systematic Reviews 2015 , Issue 9. DOI: 10.1002/14651858.CD006915.pub3.

9. Borges AM, Schaanb CW, Amantéac SL, Lukrafkad JL. Ventilação mecânica não invasiva na bronquiolite viral aguda: estudo de coorte retrospectivo. Ciência \& Saúde. 2017; 10 (4):232-238. doi:10.15448/1983$652 x .2017 .4 .26084$

10. Roquéi-Figuls M, Giné-Garriga M, Granados Rugeles C, Perrotta C, Vilaró J. Chest physiotherapy for acute bronchiolitis in paediatric patients between 0 and 24 months old. Cochrane Database of Systematic Reviews 2016, Issue 2. DOI: 10.1002/14651858.CD004873.pub5.

11. Zhang N, Wang L, Deng X, et al. Recent advances in the detection of respiratory virus infection in humans. J Med Vir. 2020; 92(4):408-417. DOI: 10.1002/jmv.25674.

12. Alidjinou KE, Lefebvre N, Dewilde A, Maki M, Hober D, Engelmann I. Evaluation of the reverse transcription strand invasion-based amplification (RT-SIBA) RSV assay, a rapid molecular assay for the detection of respiratory syncytial virus. Diag Mic Infect Dis 2019; 95(1):55-58. doi.org/10.1016/j. diagmicrobio.2019.04.006

13. Leonardi GP. Evaluation of Rapid, Molecular-Based Assays for the Detection of Respiratory Syncytial Virus. Intervirology 2019;62(3):101-104 DOI: $10.1159 / 000502995$.

14. Sanders SL, Agwan S, Hassan M, van Driel ML, Del Mar CB Immunoglobulin treatment for hospitalized infants and young children with respiratory syncytial virus infection. Cochrane Database of Systematic Reviews 2019, Issue 8. DOI: 10.1002/14651858.CD009417.pub2.

15. Griffiths C, Drews SJ, Marchant DJ. 2017. Respiratory syncytial virus: infection, detection, and new options for Prevention and treatment. Clin Microbiol Rev 30: 277-319. https://doi.org/10.1128/CMR.00010-16.

16. Kfouri RA, Sadeck LSR. Diretrizes para o Manejo da Infecção Causada pelo Vírus Sincicial Respiratório (VSR). 2017. Sociedade Brasileira de Pediatria. [Acesso em 8 abr 2020]. Disponível em: https://www.sbp.com. br/fileadmin/user upload/Diretrizes manejo infeccao causada VSR2017. pdf

17. Charlton CL, Babady E, Ginocchio CC, Hatchette TF, Jerris RC, Li $\mathrm{Y}$, et al. Practical guidance for clinical microbiology laboratories: virosis 
causing acute respiratory tractin infections. Clin Microbiol Rev 32:e004218. https://doi.org/10.1128/CMR .00042-18.

18. Barr B, Green CA, Sande CJ, Drysdale SB. Respiratory syncytial virus: diagnosis, prevention and management. Ther Adv Infectious Dis 2019; 6:1-9 https://doi.org/10.1177/2049936119865798.

19. O'Callaghan K, Jones K. Rapid testing for respiratory viruses: Impact on antibiotic use and time to patient discharge. Infection, Disease \& Health 2019; 24: 147-151. doi.org/10.1016/j.idh.2019.05.001

20. Wold Helthy Organization (WHO). Guidelines on the quality, safety, and efficacy of respiratory syncytial virus vacines. Department of Essential Medicines and Health Products (EMP), World Health Organization, Switzerland. WHO/BS/2019.2355 [Acesso em 8 mar 2020]. Disponível em: https://www.who.int/biologicals/RSV_Guidelines_Final_ BS2355_20190625-ZHOU.PDF?ua=1.

21. Corvalán LP, Arias BG, Morales SP, González MR, Inostroza SJ, Fuenzalida IL. Inmunofluorescencia indirecta versus reacción de polimerasa en cadena para el diagnóstico de virus respiratorios en niños ingresados en un hospital de la Región Metropolitana. Rev Chilena Infectol 2019; 36(1):2631. doi:10.4067/s0716-10182019000100026.

22. Liu W, Chen D, Tan W, Xu D, Qiu S, Zeng Z, et al. (2016) Epidemiology and Clinical Presentations of Respiratory Syncytial Virus Subgroups A and B Detected with Multiplex Real Time PCR. PLoS One 11(10): e0165108. doi:10.1371/journal.pone.0165108.

23. Qi J, Li X, Zhang Y, Shen X, Song G, Pan J, et al. Development of a duplex reverse transcription recombinase-aided amplification assay for respiratory syncytial virus incorporating an internal control. Arch Virol 2019; 164: $1843-1850$

24. Mesquita FS, Oliveira DB, Crema D, Pinez CMN, Colmanetti TC, Thomazelli LM, et al. Rapid antigen detection test for respiratory syncytial virus diagnosis as a diagnostic tool. J Pediatr 2017; 93 (3):246-252. doi:10.1016/j.jped.2016.06.013.

25. Kazakova A, Kakkola L, Päkkilä H, Teros-Jaakkola T, Soukka T, Peltola, et al. Serological Array-in-Well Multiplex Assay Reveals a High Rate of Respiratory Virus Infections and Reinfections in Young Children. mSphere 2019;4(5).e00447-19. doi.org/10.1128/mSphere.00447-19.

26. Caballero MT, Polack FP, Stein RT. Viral bronchiolitis in young infants: new perspectives for management and treatment. J Pediatr 2017;93:75-83. http://dx.doi.org/10.1016/j.jped.2017.07.003.

27. Díaz APV, Avendaño CLF. El virus respiratorio sincicial: patógeno de niños... y de grandes. Rev Chil Enferm Respir 2017; 33(4): 293-302. doi:10.4067/s0717-73482017000400293.

28. Bettin-Martínez A, Villareal-Camacho J, Cervantes-Acosta G, Acosta-Reyes J, Barbosa J, San Juan H. Evaluación de un método de amplificación isotérmica medida por bucle para la detección rápida del virus sincicial respiratorio en niños con infección respiratoria aguda. Biomédica. 2019;2:415-26. https://doi.org/10.7705/biomedica.v39i2.4428. 